\title{
Irk Bitig'de Karakuş, Kartal, Garuda Üzerine
}

\begin{abstract}
Ayşe Sema Uyanık*
Özet Tarih boyunca tüm toplumlar, içinde bulundukları coğrafyanın fiziki koşullarına ve toplumun kültürel değerlerine uygun olarak yaşamaya çalışmışlardır. Böylece ait oldukları toplumun kimliğini yansıtmışlardır. Türklerin benimsemiş oldukları bozkır-göçebe yaşam tarzından dolayı hayvanlar Türk topluluklarında önemli bir yer edinmiştir. Bütün milletlerin mitolojisinde hayvanlara bazı özel anlamlar yüklenmiş ve böylece bir hayvan sembolizmi oluşmuştur. $\mathrm{Bu}$ hayvan sembolizmi pek çok toplumda benzerlik göstermiştir. Geyik, at, kurt, karga, tilki, doğan ve kartal bazı sembolik hayvanlar arasında yer alır. Bu sembolik hayvanlardan kartal Türk toplumu tarafından kutsal kabul edilmiştir. Türk kültüründe kartal; hayvanata, yol gösterici, avc1-koruyucu, güçlü, zeki ve korkusuz oluşu gibi özellikleri ile ön plana çıkmıştır. Bu çalışmada Türk, Hint, İran, Yunan, Mısır ve Çin mitolojisinde yer alan kartal kavramı üzerinde durulacaktır. Ayrıca Irk Bitig'de geçen kartal kavramının hangi fallarda yer aldığ 1 belirlenecek; Budizm ile Manihaizm'de kartala hangi sembolik anlamların yüklendiği incelenecektir. Yapılacak olan bu çalışma ile Irk Bitig'de geçen kartal kavramının kültürel ve mitolojik yönüne dikkat çekilecektir.
\end{abstract}

Anahtar sözcükler: Türk Kültürü, Irk Bitig, Kartal, Garuda, Sembol

\section{Abstract About Blackbird, Eagle, Garuda in Irk Bitig}

Throughout history, all societies have tried to live in accordance with the physical conditions of the geography they live in and the cultural values of the society. Thus, they reflected the identity of the society

\footnotetext{
* Erciyes Üniversitesi Sosyal Bilimler Enstitüsü, Doktora Öğrencisi, Türk Dili ve Edebiyatı Anabilim Dalı, Eski Türk Dili Bilim Dalı, e-posta: aysesema9712@gmail.com; ORCID: 0000-0002-5293-5276
}

Received: 30.11.2021; $\quad$ Accepted: 27.12.2021;

Published: 31.12 .2021 
to which they belong. Due to the steppe-nomadic lifestyle that Turks have adopted, animals have taken an important place in Turkish communities. In the mythology of all nations, animals have some special meaning and thus an animal symbolism has been formed. This animal symbolism has been similar in many societies. Deer, horse, wolf, crow, fox, falcon and eagle are among some symbolic animals. One of these symbolic animals, the eagle was considered sacred by the Turkish society. The eagle has come to the fore in Turkish culture with its features such as being a guiding animal, hunting protector, strong, intelligent and fearless. In this study, the concept of eagle in Turkish, Iranian, Greek, Egyptian and Chinese mythology will be emphasized. In addition, it will be determined in which horoscopes the concept of eagle in Irk Bitig takes place and which symbolic meanings are attributed to the eagle in Buddhism and Manihaism will be examined. This study will draw attention to the cultural and mythological aspects of the concept of eagle in Irk Bitig.

Key Words: Turkish Culture, Irk Bitig, Eagle, Garuda, Symbol

Giriş: Geçmişten günümüze kadar olan tüm inanç sitemlerinde bir göksel varlığın mevcudiyeti görülmektedir. Özünde aynı anlamları taşıyan mitler farklı adlandırmalar ile çeşitlilik gösterebilir. Bütün milletlerin mitolojisinde olağanüstü ve büyük bir kuş dikkat çekmektedir. Göklerin kralı, yol gösterici, hayvan-ata, avc1koruyucu, güçlü, zeki ve korkusuzluğu ile bilinen kartal sadece Türk kültüründe değil diğer kültürlerde de yer almaktadır. Bu kuşun adı mitolojilere göre çeşitlilik göstermektedir. Yunan mitolojisinde Phonix, İran'da Simurg, Mısır'da Bennu, Sümerlerde Anzu, Çin'de Fenghuang, Hint'te Garuda ve Türk mitolojisinde ise Alp Kara Kuş (kartal) ve Tuğrul adlarını almıştır. Çoğu kültürde kutsallık atfedilen kartal, Mısır yazı sisteminde "A" harfi ile temsil edilmiş, pek çok farklı bölgede ve gelenekte (Şamanizm, Çin, Sümer, Hun, Japon, Hitit, Aztek, Hint, Avrupa) kötülüğün düşmanı ve sembolü olarak kabul edilmiştir (Çoban, 2015: 59). 
Farklı kültürlerde, kartala şans sembolü anlamı da yüklenmiştir. Yunan mitolojisinde Zeus'un simgesi olarak gücü, zekâyı ve kutsallığı betimleyen kartal, Mısır ve İran geleneklerinde ise güneş tanrısı olarak kabul edilmektedir. Romalılar, kartalı güç ve otoritelerinin bir sembolü olarak görmüş ve kartala "fırtına taşıyıcıları" adını vermişlerdir. Navaho Kızılderilileri ise kartalı hem çok güçlü hem de bilge bir yaratık olarak gördüklerinden kartalı, köylerinin koruyucusu olarak kabul etmişlerdir (Armutak, 2004: 150). Bazı kültürlerde ise kartalın ölümsüzlüğü simgelediği görülmüştür (Çoruhlu, 1995: 89).

Hititlerde kartal, hem kraliyet amblemi olarak kullanılmış hem de kaya ve anıtlarda bir figür olarak yer almıştır. Ayrıca çeşitli mühür ve damgaların üzerinde bulunan bir motif olması nedeniyle de dikkat çekmektedir (Chariton, 2011: 1-13).

Hint mitolojisinde kartal "Garuda" olarak bilinmektedir. Tipk1 kartal gibi o da insanların kutsallık atfettiği ve gökyüzünün hâkimi olan bir hayvandır. Yaşam ağacının dalları arasında yaşadığına inanılan garuda yılanlarla mücadelesi ile Hint mitolojisine konu olmuştur. Garuda, Hint mitolojisinde tanrının üzerine binip, yolculuk yaptığı şekilde tasvir edilir ve insanları iyileştirici özellikleri olduğu bilinmektedir (Özdağ, 2017: 23). "Gök kubbeyi, göksel ve ruhanî âlemi temsil eden bu kuş, kral Gudea'nın kadehinde, pençelerinin üzerinde ayakta duran ve bir aslanın ön pençelerine sahip olan, kanatlı kuşa benzeyen ve savaşmaya hazır olan bir canavar şeklinde yer almaktadır” (Kumru, 2017: 403).

Mısır mitolojisinde Bennu adıyla bilinen kuşun, dünyanın oluşumunda rol oynadığına ve yeniden doğuşu simgelediğine inanılmaktadır. Bennu, ayrıca çeşitli duvar resimlerinde de önemli bir figür olarak yer almaktadır (Lesuer, 2013: 35). Balıkçıla benzediği söylenen bir kuş olan Bennu, üç büyük tanrı olan Atum, Ra ve Osiris'i temsil etmekte olup Güneş tanrısı olan Atum'un sembolüdür. Yani Bennu ve güneş arasında bir bağlantı kurulduğu ifade edilmektedir. "Parlak" ve "parlaklığın yükselmesi" anlamlarına gelen Bennu, Piramit çağında yont kuşu olarak tasvir edilmiştir. Bennu kuşu kendi türünde tek kuş olup diğer kuşlar gibi 
üreyememektedir. Ömrünün sonuna geldiğini hissettiği zaman ise kokulu otlar toplayarak kendisine yuva yapmaktadır. Bazı rivayetlere göre bu otları ateşe verdiği ve bu ateşte yanarak küllerinden yeniden doğduğu söylenmektedir. $\mathrm{Bu}$ sebepten dolay1 Bennu kuşunun, kendini Ra Tapınağı'nın çevresinde olan kutsal bir ağacin alevinden oluşturduğu ileri sürülmektedir. Ayrıca diğer mitolojilerde görüldüğü gibi eski Misır'da da kartal, ölümsüzlüğün sembolü olarak görülmektedir (Akarvardar Koçak, 2021: 41-43).

İran mitolojisinde yer alan Simurg, kartalla pek çok benzer özellik taşımaktadır. "Efsanevi Kaf dağında yaşayan mitolojik ve efsanevi bir kuş olan Simurg, morğ-i morğa (kuşların şahı), morğ-i farmanrava (egemen kuş), morğ-i çarege (çare bulan kuş), morğ-i dermanger (tedavi eden kuş), sireng (otuz renk) adlarıyla da anılır. Simurg üstün zekâ ve bilgeliğe sahiptir. Bu özelliklerinden dolayı gizli sırlara vakıftır. Ayrıca simurg'un antik İran'daki konumunu, Avesta adlı eser ve Pehlevice metinlerinde izlemek mümkündür. Simurg Avesta'da "Meregu Saena" şeklinde adlandırılmıştır. Sanskritçe'de simurg yırtıcı anlamına gelen Saena sözcügü ile kuş anlamındaki murg sözcüklerinin birleşiminden oluşmuştur” (Mehran, 2017: 63).

Sümer mitolojisinde ise kartal, Anzu ya da İmdugud Muşen olarak adlandırılır. Anzu, Mezopotamya sanatının erken dönemlerden itibaren farklı hayvanlarla birlikte görülmüş ve Mezopotamya mitolojisi ve ikonografisinde aslan başlı olarak tasvir edilmiştir. Eski Sümer Devri'nde aslan başlı kartal çeşitli sanat eserleri üzerinde bulunmuş ve merkezi figürlerde iki vahşi hayvanın yerine konularak koruyucu bir görev üstlenmiştir. Ayrıca Eski Sümer Devri kişi adlarında da 'anzu'ya yer verilmiştir. Destanlarda Anzu'nun akşam yemeği için yabani boğaları yakaladığından da bahsedilmektedir. Bazı kaynaklarda ise Anzu, şeytan görünümlü olarak yer almıştır. ${ }^{1}$

Çin mitolojisinde Fenghuang adıyla bilinen mitolojik kuş, Phoenix yani Zümrüdü Anka ile pek çok benzer özelliğe sahiptir. Bu

\footnotetext{
${ }^{1}$ https://www.dunyadinleri.com/tr-TR/mitoloji/sumer-mitolojisi/oku_sumermitolojisinde-aslan-basli-kartal-anzu (20.11.2021).
} 
mitolojik kuşa, Çin Takviminde "Ağustos Horozu” adı verilmiştir. Mitlerde ölümsüzlüğü ve yeniden doğumu simgeleyen bu kuşun hayatı ve kadını temsil ettiğine inanılır. Fenghuang, fiziksel özellikleri bakımından incelendiğinde Türk mitolojisinde yer alan Tuğrul kuşuna da benzetilmektedir (Yıldırım, 2016: 4). "Kartal, Çin resim sanatında (Ying) güç simgesi olarak karşımıza çıkmaktadır. Denizdeki bir kayanın üzerinde tasvir edilen kartal ise tek başına savaşan bir kahramanı simgelemektedir. Çam ağacına konmuş bir kartal resmi, kartalın gücü ve çam ağacının uzun bir ömür yaşamak isteyen yaşlı bir erkeğe verilmesi uygun bir hediyedir" (Kumru, 2017: 403).

Yunan mitolojisinde yer alan Phoenix, uzun ömürlülüğü ve döngüsel bir biçimde hayat bulup yeniden doğması ile bilinen bir kuştur. Çoğunlukla Zeus'la özdeştirilen ve tanrıyı temsil ettiğine inanılan kartal, Yunan mitolojisinde baş tanrı olan Zeus'un yardımcısı ve en sevdiği hayvanıdır. Zeus, temiz bir kişilik ve adalete sahip olan Kral Periphas'1 bir kartala dönüştürmüş ve sahip olduğu bu özelliklerden dolayı onu tüm kuşların kralı olarak onurlandırmıştır. Bu olayın bir sonucu olarak kartal, Zeus'un asasını taşımakla görevli başyardımcı kabul edilmiştir (Gezgin, 2014: 20-21).

Hangi toplumda olursa olsun insan, doğayla ilişkisi sonucu gökyüzü ve yeryüzündeki varlıklara birtakım kutsiyetler yüklemiştir. Bu kutsiyetlerin farklı coğrafya ve kültürlerde çeşitlenmesinin sonucu olarak kartal, özünde benzer olmakla farklı adlar ile anılmıştır. Görüldüğü gibi birçok farklı kültürde kartal sembolüne rastlanmaktadır. Kartal, çok geniş bir coğrafyada ortaklaşa kullanılan bir sembol olmuştur.

\section{Türk Kültüründe Kartal}

Geçmişten günümüze kadar tüm çağlarda içinde bulunduğumuz coğrafya, inanç ve kültür sistemimizi de etkilemiştir. İnsanlar yaşamını sürdürmek için içinde bulundukları coğrafyanın fiziki koşullarına uygun bir hayat sürdürmüşlerdir. Türkler tarih boyunca göçebe-bozkır hayat tarzını benimsemiş ve göçebe hayatın getirdiği yaşam tarzını uzun süre boyunca sürdürmüşlerdir. Bunun sonucu 
olarak kültür ve inanç sistemleri de bu hayat tarzına göre şekil almıştır. Türklerin hayvanlarla olan ilişkilerinin temelinde yaşam şekilleri olan bozkır kültürü yer almaktadır.

İnsanoğlu var olduğu günden beri doğayla kurduğu ilişkilerin bir sonucu olarak, soyut kavramları maddi bir varlığa büründürme ihtiyacı duymuştur. Tabiat karşısındaki acziyetinin farkına varan insan, doğa olaylarını açıklarken kendi düşünce sisteminde kurduğu neden-sonuç ilişkileri aracılığıyla ilerlemeye çalışmıştır. $\mathrm{Bu}$ durumun bir sonucu olarak birtakım güçlere sığınma gereği duyan insan, inanç sistemlerini belirlerken, kutsal olarak gördüğü varlıklara çok farklı işlevler yüklemiştir (Kumru, 2017: 401). İnsanların doğadaki farklı güçlere sığınma ihtiyacı duymasının ve kutsallık atfetmesinin sonucu olarak çeşitli varlıkların ongun olma inancı var olmuştur. Eski Türklerin Tengricilik inancında, içerisinde bir ruha yer veren ve insanlarında o ruhtan türediği varsayılarak kutsal sayılan hayvan, ağaç, rüzgâr gibi doğal nesne ya da olaylara ya da totem gibi bir cisme ongun ad1 verilmiştir" (Esin, 2004: 230-231). “Her birisinin kendine özgü bir ongun'u olan Eski Türk boylarının, genellikle kendi boylarını koruduğuna inandıkları kutsal bir havyan türü ya da büyük bir atalarının ruhunu barındırdığına inandıkları bir cismi olmuştur. İslamiyet'ten önceki dönemlerde ise bazı Türk toplulukları belirli kuşları ongun saymışlardır. Özellikle Oğuz boylarının her dört boyu bir kuşun temsil ettiği, yirmi dört boy için tespit edilmiş altı kuş vardır" (Esin, 2006: 178-210). Ongun olarak bilinen bu kuşlar arasında kartal özel bir yere sahiptir (Esin, 2004: 231). Bu üslup içerisinde karşılaşılan kartal figürü ise Türklerin hem inanç sistemlerinde hem kültürlerinde önemli bir yer edinmiştir. Yoğun bir şekilde kullanılan bu sembollerin sıklığını, Türklerin inanç biçimleri ile açıklamak daha doğru olabilir yani Gök Tanrı ile ilişkilendirilmesi ile bağlantılı olarak, Türklerde çok eski zamanlarda bir kartal figürünün var olduğu bilinmektedir. Gök Tanrı'nın sembolü olduğu kabul edilen kartalın özellikleri, Türklerin benimsediği bozkır hayatında, zamanla dereceli bir şekilde diğer avcı kuşlara da aktarılmıştır (Kafesoğlu, 1980: 20-21). Bunlara ek olarak kartalın, Gök Tanrı'nın görünüşlerinden birini temsil ettiği 
inancı hâkimdir (Çoruhlu, 1995: 74-78). Gökyüzünün rakipsiz hâkimi olan kartal sadece gökyüzündeki kuşlar için değil, yeryüzünde bulunan diğer hayvanlar için de korkulması ve sakınılması gereken bir canlı olmuştur (İlden, 2012: 51).

Göğün en üst katında olduğu düşünülen kartal, Gök Tanrıya en yakın olarak kabul edilir. Gök Tanrıya olan bu yakınlığından dolayı kartalın kutsal özellikler taşıdığına inanılır ve bu kutsalığından faydalanmak için kartala benzemeye ve onunla bütünleşilmeye çalışılır. Çünkü kartal Tanrının temsilcisi sayılır. Kartalın asıl önemi ise onun Tanrı katına ulaşıp Tanrı ile iletişim kurup, Tanrıdan haber getirip götürmesinden yani onun, Tanrının bir elçisi ya da habercisi olduğuna inanılmasından kaynaklanmaktadır (Ögel, 1993: 47). Kartal, kuşlar içerisinde besin zincirinin tepesinde bulunan avcı bir kuş olması nedeniyle, insanlar tarafindan avda bir yardımcı yani av silahı olarak kullanılmış ve genellikle de erkek kuşlar avcı olarak yetiştirilmiştir. Avcı kuşlar, soğuk iklim etkisi ve yedikleri hayvanın renginin açık olmasına bağlı olarak ak renge sahiptirler ve avc1 olarak yetiştirilen bu kuşlar çoğunlukla komşu ülkelere hediye olarak gönderilmiştir (İlden, 2012: 51).

Eski dönemlerde birçok boy kendi topluluğunu tanımlamak için sembol kuşlar kullanmışlardır. Eski Türk boyları ise kutsal sembol olarak genellikle doğan ve kartal türünden yırtıcı kuşları belirlemişlerdir (Ögel, 1993: 593). Yırtıcı kuşlar, tüm kuşlar içerisinde, güçleri ve uçma yetenekleri açısından en fazla dikkat çeken kuşlar olmuştur. Bu yırtıcı kuşlar içerisinde kartal, dağların tepesinde ve ağaçların en üst yerlerinde yaşamıştır ve kanatlarını açtı̆̆ zaman yeryüzünü kaplayan kartal, Tanrı'nın bir habercisi olarak görülmüştür (Roux, 1994: 119). Ögel, Altaylarda kartalın eskiden beri mukaddes bir kuş olduğunu belirtmektedir (Ögel, 1988: 17). Kartal sadece güçlü kuvvetli olmasından değil aynı zamanda gözlerinin en uzak yerleri görebilmesi ve en akıllı bir kuş olarak değerlendirilmesi bakımından da önem arz etmektedir. Kartal güçlü bir fiziksel yapıya sahip olduğu için yaşam alanı olarak çoğunlukla ıssız ve ulaşılması güç olan dağ eteklerini tercih eder. İç Asya'da bulunan avcı kartallar büyük, siyah veya kahverengi, bazen de 
karışık bir renge sahip olan avcı kuşlardır. Zayıf ve kaslı vücutlara, uzun ve dağınık tüylere sahiptirler. Kanatları uzun ve sivri, kuyrukları ise kanatlarına oranla daha kısa olan kartal çoğunlukla kayalıklarda yaşamaktadır (Esin, 2004: 173). At, Türklerin düşünce sistemlerinde ve sosyal yaşamlarında vazgeçilmez bir unsur olmuştur. Türklerin hem düşünce dünyasında hem de sosyal yaşantısında vazgeçilmez bir unsur olmasıyla bilinen atın yerini göklerde ise kartal almıştır. O dönemlerde kartal Türklerin, arkadaşı ve silahı olarak görülmüş, aynı zamanda Türk aile ekonomisine de büyük oranda ortaklık sağlamıştır (Güven, 2014: 287). Bütün bu sebeplerden ötürü kartal, Türk topluluklarının büyük bir kısmında ilgi gösterilen, saygı duyulan ve değer verilen bir kuş olmuştur.

Şamanların kültüründe kartala özel bir değer verilmiş ve Şamanizm'de kartal ilk şamanın atası kabul edilmiştir. İlk şamanın ise bir kartal ile bir kadının birleşmesinden doğduğuna inanılmıştır. Ayrıca kartal şamanın sırra erişinde önemli bir rol üstlenmiştir. Şamanların bazı hayvanların şekline girdiği de bilinmektedir. Kuşların uçabilme yeteneğini üstün bir yetenek olarak gören Şamanlar, onları taklit etmeye çalışmışlardır. Kuşların özelliklerine ulaşabilmek için tüylerini, kemiklerini ve farklı parçalarını kullanarak onların gücünü elde etmeyi amaçlamışlardır. Şamanlar böyle yaparak, göklere ve göklerdeki ruhlara eriştikleri inancına kapılmışlardır. Kartal figürü, şamanların davullarında ve kıyafetlerinde sıklıkla görülmektedir (Bozdemir \& Özçelik, 2019: 110). "Türklerin millî bir simgesi olan kartal, Şamanist ayinlerde yaygın bir biçimde görülmektedir. Hatta şamanların zaman zaman bir kartal şekline girdiği, gökleri dolaştığı ve ondan sonra da yere indiği söylenmektedir. Şamanlarda her şamanın şekline girebileceği bir hayvan vardır. Fakat büyük şamanlara eş olarak daha çok kuşlar görülmektedir. Anadolu'daki eski Türk şairlerinde görülen başka bir varlığın ya da kuşun şekline girme olayı, "Donuna Girmek" deyimi ile ifade edilmektedir. Hatta hoca Ahmet Yesevi'nin "turna", Abdal Musa'nın "geyik" donuna girdiğine inanılmaktadır" (Ögel, 1993: 29-30).

Kuş motifi olarak kartal, Karakuş adıyla da bilinmektedir. Ancak 
karakuşun kartala oranla daha çok mitolojik özellikler barındırdığı düşünülmektedir. Simurg ve Zümrüdüanka ile benzer özellikler taşıyan karakuş ile Er Töştük Destanı'nda karşılaşılmaktadır. Bu destana göre Er Töştük, yaşlılık zamanında dev bir ağaç görmüştür. $\mathrm{Bu}$ ağaç o denli büyüktür ki ucu bucağı yoktur ve tepesi çok yukarıdadır. Bu devasa ağaca tırmanmakta olan Er Töştük, bir ejderha görür ve kılıcıyla ejderhayı öldürür. $\mathrm{Bu}$ devasa ağaç karakuşun yaşadığı ağaçtır. Karakuşun avlanmaya gittiği her yıl, ejderha o ağaca gelip yavrularını yemektedir. Bu nedenle Er Töştük o ejderhayı öldürmüştür. Bu destanda da görüldüğü gibi karakuşun yaşadığı ağaç uçsuz bucaksız yani göğe yakın olarak tasavvur edilmiştir (Çoruhlu, 2006: 135).

Altay mitolojisinde ise Karakuş; Karaguş, Harahus ve Karakuş Han adlarıyla da bilinmektedir. Kuşların hükümdarı olarak görülen karakuşun, Tanrı Ülgen'in oğlu olduğuna inanılmaktadır. Türklerde, kuşların ruhları temsil ettiği inancı hâkimdir. Bu duruma kamların katıldıkları ayin törenlerinde de rastlanmaktadır. Şamanların ayinlerinde kullandıkları davulların üzerinde yer alan kartal, Karakuş olarak geçmektedir (Özdağ, 2017: 23).

Kartal anadan doğduğuna inanılan şamanların, oldukça güçlü şamanlar olduğu inancı hâkimdir. Çünkü bu şamanların yer altına veya gökyüzüne yaptıkları yolculukları sırasında kartal ruhunun şamanlara yardımcı olduğu ve onları başarıya ulaştırdığı düşünülmektedir. Altay Türkleri kartalı, Tanrı ile aralarında bir elçi olarak görmüşlerdir (Ögel, 1993: 48).

Yakut Türklerinde de şamanlar ile benzer bir inanış görülmektedir. Onlarda kartalın göklerde hâkim güç olduğuna ve Gök Tanrı ile iletişimi sağlayan bir elçi olduğuna inanmışlardır. Kartal, Yakut Türklerinde, en yüce ruhları taşıyan bir hayvan olarak bilinir. Şaman ruhunu ve Gök Tanrı'yı temsilen Dünya Ağacının üstünde düşünülmüştür. Hayvan-ata ya da yardımcı ruhları temsil etmek için şaman elbiselerinde kartal figürüne yer verilmiştir. Şaman elbiselerinde bulunan bu kartal figürü önemli bir türeme simgesidir (Özkartal, 2012: 63-64).

"Şamanlar, giysilerini kuş tüyleriyle donatarak kartala benze- 
meye çalışmışlardır. Şamanların bu giysilerine "manyak" adı verilmiştir. Şamanların giysisi olan "manyak"ın iki omzuna dikey bir şekilde bağlanan baykuş, kartal ve puhu kuşu tüylerinden oluşan iki demet yerleştirilirdi. Manyak'ın kuşağına bağlanan saçaklı, işlemeli ve puhu kuşu ya da kartal tüyleri asılı olan örgü, yere kadar uzanırdı. Şamanlar her türlü hareketlerinde, oyunlarında ve giyimlerinde kartalı taklit etmeye çalışmışlar, elbiselerine ya kartal tüyleri ya da beyaz ve mavi renkteki kumaş parçaları bağlamışlardır" (Güven, 2014: 293). Şamanların yaşamında kartalın çok aktif bir rol oynadığı, giysileriyle kartal görüntüsü oluşturmaya çalıştıklarından da anlaşılmaktadır.

Ayrıca Türklerde dünya ağacının tepesinde oturan bir "çift başlı kartal” sembolü yer alır. Bu kartal gökleri korumakla görevlidir. Yakutlarda ise şehir merkezlerine gök direği adı verdikleri sırıklar dikilir ve tepesinde çift başlı bir kartal bulunur. Bu konuda şu görüşler öne sürülmüştür;

Ögel, göğün en zirvesinde bulunan ve göğün yere açılan kapısında, yer ile göğü birbirine bağlayan Dünya Ağacının en üstünde çift başlı bir kartal oturduğunu ve bu çift başlı kartalın görevinin göklerin korunması olduğunu ifade eder (Ögel, 1995: 289). Yakutlar, "gök direği” adını verdikleri ve üzerinde ağaçtan yontulmuş, "gök kuşu” diye adlandırılan çift başlı kartalın yer aldığı sırıkları, şehir merkezlerine dikmişlerdir. Bu sırığın, hayat ağacını ifade ettiğine inanılmış ve zihinlerde dünyanın direği olarak canlandırılmıştır. Ayrıca bu gök direğinin göğe kadar uzandığına inanılmış ve gök direğinin üzerinde bulunan çift başlı kartal, kuş şeklindeki ruhların koruyucusu olarak düşünülmüştür (Ögel, 1993: 598). Çoruhlu (1995: 86)'da Başkurt folklorunda bulunan iki başlı kuşun, çift başlı kartalla ilişkilendirilebileceğini söyler.

Türk kültür tarihinde yer alan kartalla ilgili motifler, arkeolojik eserlerde de tespit edilmektedir. M.Ö. V. ve IV. Yüzyılda Altaylara ait olan Pazırık Kurganı I'de kartal figürüne dair ilk bulguya rastlanmaktadır. $\mathrm{Bu}$ arkeolojik bulguda, bir eyer örtüsü üzerine deriden aplike olarak işlenmiş bir süsleme bulunur. Bu süslemede kartal bir griffon'un geyik ile karşılıklı mücadelesi anlatılmaktadır. 
Kartal motifi bir geyiği pençeleri ile yakalayarak havada uçururken betimlenmiştir (Diyarbekirli, 1972: 83). Pazırık Kurganı II'de ise atların üzerinde bulunan eyerin kaplamaları kartal griffon ile süslenmiştir. Bu griffon, ölü odasındaki tabutun baş tarafında yer almaktadır. Kartal griffonu, ağaçtan yontulmuş ve karışık bir biçimdedir. Bu nedenle bu griffon dikkat çekicidir (İnan, 1952: 137138).

Hun mezarlarında bulunan ve çok büyük önem arz eden üç kartal resmi gök bilimi ile ilgili semboller taşımaktadır. Bu kartal resimlerinin altında bulunan ay ve yıldızlar göğ̈ temsil ederler. Ters bir şekilde yer alan yıldızlar ise gece ve gündüzü simgelemektedir. Eski Türklerin inancına göre gece ve gündüz göğün üzerinde durmaksızın dönmektedir. Tamamen gece olmasının ardından karanlık oluşmaktadır. Hun mezarlarında rastlanan bu resimlerde dünya üstünde dönmekte olan, siyah ve beyaz renkli kartal bulunmaktadır (Ögel, 1972: 217).

\subsection{Budist Uygurlarda Kartal}

"Garuda, Budist metinlerinde Garula olarak da adlandırılan altın kanatlı kuşlardır. Budist geleneklerinde, Hindu sanatında olduğu gibi, hem zoomorfik (dev kartal benzeri kuş) hem de kısmen antropomorfik (kısmen kuş, kısmen insan) ikonografisi yaygındır. Garuda, Hinduizm ve Budizm'deki kuşların efsanevi efendisi olarak bilinir."

Tokyürek, kanatları altın olan bu mitolojik kuşun en büyük düşmanının yılan olduğunu söyler. "Bu kuş, Skr. garuḍa ve Çin. 迦 樓羅 garuda luo olarak tanımlanır ve tanrı Viṣnu ya da Buddha ile ilişkilendirilir. Aynı zamanda, hızlı uçmasından ötürü lider olarak kabul edilmektedir. Boynunda bir zümrüt bulunduğu söylenen kuş, ayrıca, tanrı Viṣnu'nun taşıtı olarak da bilinmektedir. Tanrı Vişnu'nun taşıtı olarak bilinmesine Eski Uygurcadaki "garudl kölüklüg vişnu teyri (Zieme 2005: A, 85-86) Garuḍa taşıtlı Viṣṇu

${ }^{2}$ http://www.chinabuddhismencyclopedia.com/en/index.php/Garud a, The Eagle King (20.11.2021). 
Tanrı" örneği verilebilir. Ayrıca "ol teyriler luular yekler gandarvilar garudılar (Kaya 1994: 400, 17-18) O tanrılar, ejderhalar, şeytanlar, gandharvalar, garuḍalar" örneği de bu kuşun kutsal olduğunu göstermektedir. Aynı zamanda garuda, Çin'de dört mevsimle ilişkilendirilmiştir. Yaz mevsimini temsil ettiği söylenen garuda, yaz mevsimine bağlı olarak gençliği de simgelemektedir. Garuḍa kuşu, beş Dhyāni Buddha'dan Amoghasiddhi'yi, beş Dhyāni Bodhisattva'dan Viśvapāni'yi ve Maitreya Buddha'yı da ifade eder. “yaya yuy kuş at garudı arslanlig örgünlerte yarp ornanmış edgün barmış biş kaylarka (Kaya 1994: 678- 679, 23-1) Fil, tavus kuşu, at, garuḍa ve aslanlı tahtlarda sağlamca yerleşmiş iyilikten gelmiş beş hükümdarlara." Örneğinde olduğu gibi garuḍa aynı zamanda Buddha'yı tanımlamaktadır" (Tokyürek, 2013, 227).

Uygurlarda kartal ve onun gibi yırtıcı kuşlar, çocuk kaçırmak ya da göğe yükselmek için bir binek olarak kullanılmıştır. Hakanlılarda, önceleri Hint mitolojisindeki garuda'ya benzetilen karakuş, sonraki dönemlerde karakuş veya burgut adı verilen avcı kartalı andırmıştır (Esin, 2004: 172-173).

Karakuş, Eski Türklerin ön Asya kültürlerinde ise "Mizân" veya “Terazi” denilen burca ad olarak kullanılmıştır (Ögel, 1995: 75-77). Ayrıca Budist ve Budist olmayan Türk mitoloji sanatında, Hint masallarına Garuda ismiyle konu olan akbaba, Garudi, Karuti ve Karakuş adlarıyla var olmuştur. Özlem Civelek, karakuşun kara ve kuş sözcüklerinden oluşan birleşik bir isim olduğunu söyler ve karakuşun diğer dillerde şu şekilde geçtiğini ifade eder: Ar. al uqab, Lat. aquila, Rus. Беркут, Moğ. Bürgüd, Sansk. grdrakuta, Çin. jiu (Civelek, 2008: 89). Mitolojik sembol olarak da kullanılan karakuşa, Orta Asya Budist sanatında, Kök Türk ve Batı Türk (550-744) ile Uygur (850-1220) dönemlerinde çokça rastlanmaktadır. Bu kuş, karışık renkli bir kuyruğu veya kanatları olan bir akbaba veya kartal gibi kulaklı şekilde tasvir edilmiştir. Bu sembole hem İslami Türk devrinde hem de Hakanlı ve Selçuklu devrinde kulaklı şekliyle rastlandığı görülmekte olup “Altın kanatlı" kuş adıyla bilinmektedir. Sonraları bu ad yerini “Karakuş” (tavşancıl kartal)'a bırakmıştır (Esin, 2004: 172-173). 
Tokyürek'e (2013: 228-229) göre; "Eski Uygur metinlerinde "manu irbiz tilkü karsak yuy kara kuş ulatı et yédeçi kan içdeçi tınlıglar (Kaya 1994: 599, 15-17) Kedi, vaşak, tilki, step tilkisi, tavus kuşu, kartal ve et yiyici, kan içici canlılar” örneğinde olduğu gibi kartal vahşi bir hayvan olarak tanımlanmakta ve Skr. kinnara terimi ile adlandırılmaktadır. Kinnara, Budizm'de insan olmayan varlıklardan biri olarak kabul edilmiştir. Sıralaması Tanrılar, kinnaralar, nāgalar, şeytanlar, rakșalar olan bu varlıkların hepsi karanlığın canlıları olarak yer almaktadır. Buna örnek olarak "sansız sakışsız teyriler ulug küçlüg luular gantarvılar asurlar telim karakuş hanlar kinarilar (Bang-Gabain vd. 1934: 431-432) Sayısız tanrılar, güçlü ejderhalar, gandharvalar, asuralar, pek çok kartal hanı kinnaralar" örneği verilebilir. Ayrıca 緊那羅 kinnaralar, Kuvera'nın müzisyenleri olup insan vücutlu ve at başlı olarak da tanımlanmış ve cennetin sekiz müzisyeni arasında yer almıştır. Budizm'de önemli bir yer olan Akbaba kayalığı/zirvesi ya da Kartal kayalığı/zirvesi anlamına gelen Skr. grdhrakūṭa kelimesinin Türkçe karş1lı̆̆ 1 Karakuştur. Skr. griddha "akbaba" anlamına gelir. Çinli tercümanlar ise genellikle Çin. 靈熟山 líng jiùshān "kutsal kartal zirvesi”" ifadesini kullanmışlardır. Nagarjuna ise, dağın zirvesi kartal şeklinde olduğu için bu ismi aldığını söyler. Kartal zirvesi ile Buddha alanını sembolize edilmekte olup genellikle kartal zirvesinin temiz alanı olarak isimlendirilir. Bu dağda, Śākyamuni Buddha Lotus Sūtra'sını ve diğer öğretilerini açıklamıştır. Eski Uygurcadaki "karakuş seyirlig tagıg (Röhrborn 1996: 678-679) Kartal kayalıklı dağı”, "karakuş senirlig arıg ol gratırakut tagda (Kaya 1994: 682, 22-23) Kartal kayalıklı mukaddes Gṛdhrakūṭa Dağında” örnekleri yer alır.

\subsection{Irk Bitig Metninde Kartal}

Fal Kitabı adını taşıyan Irk Bitig tahminen 930 yılında Köktürk alfabesi ile kaleme alınmıştır. Genç bir mürit tarafından, ağabeyi Sangun İtaçuk için "Pars yılının ikinci ayının on beşinci gününde (9. yy)” Taygüntan manastırında yazılmıştır (Seçkin, 2015: 1434). Doğu Türkistan'daki Bin Buda Mağaralarından getirilen eser, Londra'da yer alan British Museum'un doğu yazmaları bölümünde 
8212 numarada bulunmaktadir. Yazma halindeki bu eser, 57 yapraktır ve 13,6 X $8 \mathrm{~cm}$ ebatındadır. Yaprakların arka ve ön yüzleri yazılı olup ve her yüzde 6 ile 10 arasında değişen satır yer almaktadır. Alt tarafı zamkla yapıştırılmış olan kitap ciltli değildir (Kaya, 2008: 1). Irk Bitig üzerine yapılan çalışmalardan ilki Vilhelm Thomsen'e aittir. Thomsen, çalışmasını 1912 yılında Journal of the Royal Asiatic Society adlı dergide yer alan "Dr. M. A. Stein's Manuscripts in Turkish 'runic' Script from Miran and Tun- Huang" adlı makalesinde yayımlamıştır (Yıldırım, 2017: 22). Thomsen'dan sonra eseri Hüseyin Namık Orkun 1938 yılında yayımladığı Eski Türk Yazıtları II'de, Thomsen'in bazı kelimeleri yanlış okuduğunu düşünerek, o yanlışları düzeltip tekrar yayımlamıştır. 1951 yılında ise Malov, Thomsen'ın yayınını Rusçaya çevirmiştir. Bu çalışmalara ilaveten Teruyuki İkeda, Willi Bang, Sir Gerard Clauson, Marcel Erdal ve Talat Tekin gibi birçok bilim insanı, Irk Bitig'i yayımlamıştır (Seçkin, 2015: 1434).

Irk Bitig, kısa cümlelerden oluşan bir anlatıma sahiptir. Kısa cümlelerin tercih edilmesi, falların anlaşı1ır ve etkili olmasında önemli bir etken olmuştur (Yıldırım, 2017: 53). Irk Bitig, eski Türklerin siyasi yaşamına, dinî inançlarına ve sıradan insanların gündelik ilişkilerine dair bilgiler sunan fallardan oluşmaktadır. $\mathrm{Bu}$ fallar, iyi ve kötü ilişkisi üzerine kurulmuştur. Bu ikilik ise genellikle metinde bir olay üzerinden aktarılmaktadır. Böylelikle hem bireyin hem de toplumun bu durumdan ders çıkararak hareket etmesi için öğüt verilmek istenmektedir (Seçkin, 2015: 1433). Eser içinde dinî unsurlar bulundurmakla birlikte dinî bir eser olmayıp bir fal kitabıdır. Toplamda 65 paragraftan oluşan eserin her paragrafı ayrı bir fal olarak yorumlanmıştır. Falların başında siyah mürekkeple çizilmiş ve üç dizi biçiminde olan küçük daireler yer alır. Dizilerdeki dairelerin sayıları 1 ile 4 arasında değişmektedir. Bu nedenle her fal, üç rakamlı bir sayı ile numaralanmış gibi görünür. Her fal, önce üç şans sayısı, daha sonra fal metni, en son olarak da falın iyi ya da kötü olduğunu belirten bir sonuçtan oluşmaktadır. Şans sayıları 2-1-4 gibi bir biçimdedir. Bu sayılar 1 ile 4 arasındadır. Şans zarının veya kemiğinin art arda üç defa atılmasıyla şans sayıları elde edilmektedir 
(Kaya, 2008: 3). "İlgi çekici bir yapısı, dili ve üslubu olan Irk Bitig'de, her fal; "şöyle bilin(iz) iyidir" veya "şöyle bilin(iz) kötüdür" şeklinde bir hüküm ile bitmekte olup, hüküm cümlesinden önce "der" bazen de "demiş" kelimesi bulunmaktadır. Asıl fal, bu “der” kelimesinden önce yer alır ve birkaç kısa cümleden meydana gelir" (Ercilasun, 2014: 232).

Irk Bitig, Mani sahasında ele alınmış bir metin olmakla beraber bu konuda bazı tartışmalar mevcuttur. Vilhelm Thomsen, Irk Bitig'in Manihaist bir çevrede yazılmış olabileceğinden söz eden ilk kişidir (Yıldırım, 2017: 53). Bu görüşün yanı sıra Tezcan'a (1978) göre "Irk Bitig metninin Manihaist bir çevrede yazıldığı düşünülüyorsa da, eserde ne Manihaizm, ne de başka bir dinle ilgili herhangi bir iz yoktur (Tezcan, 978; akt. Kaya, 2008: 1)."

Irk Bitig'de bulunan 65 falın 39'unun sonucu olumlu, 19'unun sonucu ise olumsuzdur. Geriye kalan 7 fala ise herhangi bir yorum getirilmemiştir. Irk Bitig'de yer alan 65 falın birçoğunda hayvanlar yer almaktadır. Kartal gibi mitolojik hayvanlar veya mitolojik kavramlar, adlarının ötesinde çok derin anlamlar taşımaktadırlar. Irk Bitig'de 3, 43 ve 51. falda geçen kartal "karakuş" olarak adlandırılmaktadır. Bu üç falda da kartal "yırtıcı bir kartalım" şeklinde geçmektedir. 3. falda diğer fallardan farklı olarak kartalın altın kanatlı olduğu vurgulanmış ve "altın kanatlı yırtıcı kartalım" şeklinde geçmektedir.

Bu falları şöyle sıralamak mümkündür;

3.fal: altın kanatlıg talım karakuş men. tanım tüsi takı tükemezken taluyda yatıpan tapladukumın tutar men. sebdükümin yèyür men. antag küçlüg men. ança biligler; edgü ol

Çeviri: "Altın kanatlı yırtıcı bir kartalım. Vücudumun tüyleri henüz tam büyümemişken denizde yatarak dilediğimi tutuyor, sevdiğimi yiyorum. $\mathrm{O}$ kadar 
güçlüyüm. Öylece biliniz: (Bu fal) iyidir.” (Yıldırım, 2017: 35).

43.fal: togan ügüz kuşı kuşlayu barmış. utru talım karakuş kopupan barmiş tèr. ança biligler: yablak ol.

Çeviri: "Bir doğan, su kuşu avlamaya gitmiş. (Bu sırada) yırtıcı bir kartal yerinden uçup (doğana) karş1 gitmiş. Öylece biliniz: (Bu fal) kötüdür." (Yıldırım, 2017: 43).

51.fal: talım karakuş men. yaşıl kaya yaylagım, kızıl kaya klşlağım ol. tagda turupan menileyür men. Ança biligler:

Çeviri: "Ben yırtıcı kartalım. Yeşil kaya yaylam, kızıl kaya kışlağımdır. Dağlarda kaldığım için mutluyum. Öylece biliniz.” (Yıldırım, 2017: 45).

$\mathrm{Bu}$ üç fala bakıldığında 3. fal iyi, 43. fal kötü ve 51. fal ise yorumsuz bırakılmıştır. Yıldırım, Irk Bitig metninde bazı fallarda konuşan varlıkların olduğunu söyler. Bu varlıklar konuşmaya önce kendilerini tanıtarak başlar daha sonra ise çeşitli özelliklerinden bahsederler (Yıldırım, 2017: 56). 3. falda konuşan canlı varlık 'altın kanatlı yırtıcı bir kuş'tur. 43. falda, bir canlı varlık konuşmamış bir olay anlatılmıştır. 51. falda ise yine bir canlı varlık konuşmaktadır. Bu canlı varlık 'yırtıcı bir kartal'dır.

Irk Bitig'de kartal kelimesi için "karakuş" kullanılmıştır. Araştırmacılar 'karakuş'un kartal olduğunda hem fikirdir. $\mathrm{Bu}$ konuda ilk olarak Thomsen, ardından Erdal Irk Bitig'de geçen 'karakuş'un, Hint mitolojisine, kuşların kralı ve göklerin hâkimi olmasıyla ayrıca, yılanlarla yaptığı mücadeleler ile konu olan Garuda ile pek çok benzer özelliğe sahip olduğunu söylemektedir 
(Yıldırım, 2017: 57). Karakuş ifadesinin geçtiği bu üç fal incelendiğinde karakuşun temsil ettiği özellikler şöyle sıralanabilir:

3. falda altın kanatlı ve çok güçlü olarak geçmektedir. Kartalın burada taşıdığı anlam diğer kültürlerde de görülmektedir. Zaten kartalın kutsanmasının en önemli nedenlerinden birisi de gücü ve zekâsıdır. 43.fal da ise yırtıcı bir kartal olarak geçmiş ve yine kartalın güçlü olma özelliği ön plana çıkarılmıştır. Yırtıcı olmasının sebebi diğer hayvanlarla yaptığ mücadelesinden kaynaklanmaktadır. Hint mitolojisinde Garuda yılanlarla, Sümer mitolojisinde Anzu yabani boğalarla, mücadele etmekteydi. 51. fal da ise hem yırtıc1 olma özelliği tekrarlanmış hem de dağlarda yaşadığı ve bu durumdan mutlu olduğu belirtilmiştir. Türk kültüründe ve diğer kültürlerde de olduğu gibi yüksek yerlerin kutsal sayılması inancı vardır. Çünkü bu yüksek yerler tanrıya en yakın olan yerlerdir. Bir dağ tepesi ya da bir ağaç tepesi bu şekilde görülebilir. Türk kültüründe de dünya ağac1 olarak geçen ve üzerinde çift başlı bir kartal olan ağaçta bu şekilde değerlendirilmektedir. Hint mitolojisinde garuda olarak bilinen kartal da yaşam ağacının dalları arasında yaşamaktaydı. İran mitolojisine ait bir kuş olan Simurg ise efsanevi Kaf dağında yaşamaktaydı. Ayrıca karakuş ifadesi Budizm'de önemli bir yer olan ve Akbaba kayalığı/zirvesi anlamındaki Skr. gṛdhrakūṭa kelimesinin de Türkçe karşılığıdır. Irk Bitig'de yer alan bu 3 falda karakuş olarak geçen kartal, diğer kültürlerle ortak anlamlar taşımaktadır. Ortak anlamlar taşımasında Eski Türk kültürünün karma bir yapıda olması etkili olmuş olabilir.

Sonuç: Türkler içinde bulundukları her dönemde hayvanlara özel anlamlar ve kutsallık yüklemişler ve bu hayvanları hayatlarına ortak etmişlerdir. Bu hayvanlardan biri olan kartal, Türklerin yaşam ve inanış biçimleriyle ilgili olarak bazen yol gösterici, bazen avc1koruyucu bazen de hayvan-ata olarak; gücün, hükümdarlığın, kutsallığın önemli bir temsilcisi olmuştur. Kartalın güçlü, zeki ve korkusuz olması onun bir simge olarak kullanılmasında etkili olmuştur. Kartal, göğün rakipsiz hâkimi olarak kabul edilir ve sonsuzluğu simgeler. Ayrıca Türk mitolojisinde yer alan çift başlı 
kartal da dünya ağacının tepesinde görülmektedir. Kartalın avc1koruyucu olarak tasavvur edilmesinde Türklerin yaşam tarzının büyük bir etkisi vardır. Kartal, Şamanist inançta özellikle Yakut Türklerinde özel bir yer edinmiştir. Hun İmparatorluğu'ndan itibaren kartalla ilgili arkeolojik buluntulara rastlanmaktadır. Görüldüğ̈̈ gibi kartal figürü, Türklerde çok uzun bir tarihsel geçmişe sahiptir. Türk mitolojisinde kartal, karakuş olarak da ifade edilmiştir ve bu anlamı ile Irk Bitig metninde karşımıza çıkmaktadır. Kartal ve taşıdığı anlam ile ilgili olarak diğer mitoloji ve kültürlere bakıldığında hemen hemen hepsinin temelinde benzer anlamlar olduğu görülmüştür. Fakat her toplum kartala, kendi kültürüne ve yaşam şartlarına göre özel anlamlar yüklemiştir.

Kisaltmalar

Çin.: Çince

M.Ö.: Milattan önce

Skr.: Sanskritçe

\section{Kaynaklar}

Akaravardar Koçak, S., Z. 2021: "Güneşin Kanatları: Simurg". Çocuk ve Gençlik Edebiyatı Dergisi Inceleme Araştırma Eleştiri, Sayı 3, s. 38-48.

Armutak, A. 2004: “Doğu ve Batı Mitolojilerinde Hayvan Motifi II. Sürüngenler, Balıklar, Kanatlılar ve Mitolojik Hayvanlar”. İstanbul Üniversitesi Veterinerlik Fakültesi Dergisi, Cilt 30, Say1 2, s. 143-157.

Bozdemir, O., Özçelik, H. 2019: "Şamanist Ritüeller Kapsamında Şaman Davulunda Bulunan Sembollerin Değerlendirilmesi Üzerine Bir Araştırma”, Akademik Sanat; Sanat, Tasarım ve Bilim Dergisi, DOI: 10.34189/asd.4.8.008. 
Chariton, J. D. 2011: “The Mesopotamian Origins of the Hittite Double-Headed Eagle". UW-L Journal of Undergraduate Research, Say1 14, s. 1-13.

Civelek, Ö. 2008: "Karakuş", Av ve Avcılık Kitabı, Ed. Emine Gürsoy Naskali, Hilal Oytun Altun, İstanbul: Kitapevi, s. 89101.

Çoban, İ. 2015: “Türk İkonografisinde Kartal Motifi ve Çağdaş Türk Resim Sanatına Yan1sımaları”, Idil Sanat ve Dil Dergisi, Cilt 4, Say1 16, s. 57-80.

Çoruhlu, Y. 1995: Türk Sanatında Hayvan Sembolizmi, İstanbul: Seyran Kitap. , 2006): Türk Mitolojisinin Anahatlarl, İstanbul: Kabalcı Yayınevi.

Diyarbekirli, N. 1972: Hun Sanatı, İstanbul: Milli Eğitim Bakanlığ1 Kültür Yayınları.

Ercilasun, A. B., 2014: Başlangıçtan Yirminci Yüzyıla Türk Dili Tarihi, Ankara: Akçağ Yayınları.

Esin, E. 2004: Orta Asya'dan Osmanlyya Türk Sanatında İkonografik Motifler, İstanbul: Kabalcı Yayınları. , 2006: Eski Türklerde Maddi Kültürün Oluşumu, İstanbul: Kabalcı Yayınevi.

Gezgin, D. 2014: Hayvan Mitosları, İstanbul: Sel Yayınc1lık. 
Güven, M. 2014: “Türk Halk Oyunlarında Kartal Figürü”, Atatürk Üniversitesi Türkiyat Araştırmaları Enstitüsü Dergisi, Sayı 51, s. 285-302.

İnan, A. 1952: “İkinci Pazırık Kurganı”, Belleten, Cilt 16, Sayı 61, s. $137-140$. , (1986). Tarihte ve Bugün Şamanizm Materyaller ve Araştırmalar, Ankara: Türk Tarih Kurumu Basımevi.

Kafesoğlu, İ. 1980: Eski Türk dini, Ankara: Kültür Bakanlığ1 Yayınları.

Kaya, C. 2008: "Irk Bitig'de falc1lık", Kültür Tarihimizde Gizli Diller ve Şifreler (Ed. Emine Gürsoy Naskali, Erdal Şahin), s. 359-368.

Kumru, C. 2017: "Eski Türk Kültüründe Kartal Simgesi”, I. Uluslararası Türklerin Dünyası Sosyal Bilimler Sempozyumu, Antalya (11-14 Mayıs).

Lesuer, R. B., 2013: "Between Heaven And Earth-Birds in Ancient Egypt”. Chicago: Oriental Institute Museum Publications 35.

Mehran, S. 2017: Simurg, Sosyal Bilimler Enstitüsü, Yüksek Lisans Tezi, Erzurum.

Ögel, B. 1988: Íslamiyet'ten Önce Türk Kültür Tarihi, Ankara: Türk Tarih Kurumu Basımevi. , 1993: Türk Mitolojisi I, İstanbul: Milli Eğitim Basımevi. , 1995: Türk Mitolojisi II, İstanbul: Milli Eğitim Basımevi. 
Özdağ, D. E., 2017: “Çağdaş Türk Sanatında Gerçek Dışı Kuş Figürleri”, Didar Ezgi Eğitim ve Toplum Araştırmaları Dergisi/JRES, Cilt 4, Say1 1, s. 17-32.

Özkartal, M. 2012: “Türk Destanlarında Hayvan Sembolizmine Genel Bir Bakış (Dede Korkut Kitabı'ndan Örnekler)”, Millî Folklor, Y11 24, Say1 94, s. 63-64.

Roux, J. P. 1994: Türklerin ve Moğolların eski dini, (çeviren Aykut Kazancıgil). İstanbul: İşaret Yayınları.

Seçkin, K. 2015: “Irk Bitig: Toplumsal İyi ve Toplumsal Kötünün İnşasında İdeolojik Bir Fal Kitabı”, Uluslararası Türkçe Edebiyat Kültür Eğitim Dergisi, Say1: 4/4, s. 1433-1450.

Tokyürek, H. 2013: “Eski Uygurcada Hayvan Adları ve Bunların Kullanım Alanları", TÜBAR (Türklük Bilimi Araştırmaları), Say1 33, s. 221-281.

Yıldırım, B. B., 2016: "Mitolojide kullanılmış olan hayvan figürlerinin seramik yüzeylerde kullanımları, anlamları ve Türk sanatına etkileri”, 10. Uluslararası Eskişehir Pişmiş Toprak Sempozyumu, s. 737-757.

Y1ldırım, F. 2017: Irk Bitig ve Orhon Yazılı Metinlerinin Dili, Ankara: Türk Dil Kurumu Yayınları.

\section{Web Kaynakları}

https://www.dunyadinleri.com/tr-TR/mitoloji/sumermitolojisi/oku_sumer-mitolojisinde-aslan-basli-kartal-anzu (20.11.2021). 
http://www.chinabuddhismencyclopedia.com/en/index.php/Garuda The Eagle_King (20.11.2021). 